\title{
CONSULT YOUR LOCAL LISTINGS
}

I am surely not the first to note that most of what appears on the television is trivial. But how do those little magazines that specialize in program listings manage somehow to make it appear even more trivial than it is? They have a positive genius for trivializing the trivial. They have mastered a certain flatness of style, so that every conceivable form of human activity sounds in the end quite ordinary and commonplace, and all right. They have discovered the monotone in literary style, which lulls the reader unwittingly into a sense that life and history unfold without benefit of peaks and valleys, and that all's well with the universe, albeit a little dull. Can it be that our civilization is collapsing, neither with bang nor whimper, but just a complacent yawn?

Here are two samples from yesterday's listings. "Maude: Helen Page Camp and James Coco play a liberated couple eager to initiate the Findlays into the sophisticated world of suburban wife-swapping. Maude: Beatrice Arthur. Walter: Bill Macy." (Am I expected to know who Helen Page Camp is? and Bill Macy? and Walter? Should I be concerned that, although I have long been a suburbanite, I seem to have been missing out on all this sophistication? What would Helen and Jim think if they ever moved into this neighborhood, jam-packed with unliberated couples and unswapped wives? The guide makes it all seem so near at hand, so familiar, so matter-of-fact. Where have I been?)

The truth is I haven't been watching Maude. But I do have a weakness for old movies. Here is one listed, "Svengali: Venerable tale of the hypnotist who casts a spell over a girl and makes her a famous singer. On the heavy side."

We all know that film-makers delight in producing films on religious themes: biographies of prophets and heroes, lives of holy men, adaptations of Biblical tales. And we got to thinking how the writers of these guides would sum up the plots of these films-some of which, we confess, have not yet been made, but surely sooner or later will: only to make the rounds of the local television stations after their newness is worn off. Here is how we expect to see them listed:

JESUS OF NAZARETH: Young man begins practising medicine on his day off, and comes acropper of the authorities. Jesus: Horst Buchholst.

PRINCE GAUTAMA: Young man raised in marble palace shows symptoms of mild depression, takes up meditation. Good characterization, but not much action.

MUHAMMAD, PROPHET OF GOD: Middle-aged merchant's young wife becomes concerned when her husband reports encountering a winged angel in a cavern. Fine desert scenery.

HARE KRISHNA: In this import from France, a darkly handsome youth frolicks tirelessly with the girls of his quaint village. (Not to be confused 
with the more recent American version, a simple musical devoid of plot.) Radha: Catherine Deneuve. Krishna: Jacques Tati.

GIVE ME THE MOON OVER BROOKLYN: Korean evangelist purchases all of Flatbush, and announces intentions of rebuilding Ebbets Field, arousing suspicions of local Hassidim. Rebbe: Lee J. Cobb.

CONFUCIUS SAY: A Taiwanese remake of "The Late George Apley." Too talky.

MOSES: Hot-tempered Egyptian entertains pretty daughter of mountain priest with wonder tales of his life. A bit far-fetched, but vivid landscapes. Moses: Dustin Hoffman.

LAO TZU: Aging archivist receives useful advice from shrewd gatekeeper on how to write a best-seller. (Lao's water buffalo received the 1967 Emmy Award for Best Supporting Role by an Animal.)

MAX MÜLLER IS MY NAME: Famed philologist of Victorian times reveals himself to be a solar myth, to the dismay of his housekeeper. Costume drama.

MOUNT SINAI: Energetic mountain climber achieves his goal, but encounters many surprises on the way, causing his conscientious brother to abandon his dream of becoming a sculptor and enter the priesthood.

DAVID AND BATHSHEBA: Restless potentate of tiny mid-Eastern monarchy builds watchtower on palace roof, with diverting results.

ZARATHUSTRA!: Unknown Persian anticipates discovery of the light bulb. Ahriman: Vincent Price.

EUROPA AND ZEUS: Plump country girl forms attachment to bovine companion. Labyrinthine complications ensue.

LEDA: Aging deity, intent on trying his hand at being a "swinger," adopts unusual disguise. Set to quaint musical score by familiar Russian composer, with authentic ballet sequences filmed on location in Moscow.

RAMAYANA: In this lengthy Indian remake of "Planet of the Apes," an army of flying monkeys invades the island of Ceylon to settle a marital dispute.

SONG OF THE LORD, or BHAGAVAD-GITA: Bashful warrior is given good talking to by his down-to-earth charioteer, played here by an aging Wallace Beery.

TOWER OF BABEL: Work at a giant construction project is halted by ethnic frictions.

NOAH'S ARK: Amateur boatman brings first voyage to unsteady conclusion with aid of avian pet.

KIERKEGAARD: Moody Dane breaks off with his girlfriend. Stars Liv Ullman. 
Just what is the difficulty with this style of writing? Wherein lies the fallacy? Is it that what happens, in fiction or film, isn't what really matters? That in summarizing simply the plot, we omit the heart of the work (if, indeed, it had any)? Jack Hawkins' superb film, "Outcast in Malaya," is reduced to "the domestic problems of a rubber planter and his wife are solved by approaching jungle terrorists," and Dickens' "Pickwick Papers" to an "eye-opening tour of Britain."

That surely is at the nub of the problem. Great fiction and great film reflects life. And life, in an odd sort of way, isn't "about" anything. It isn't what happens that matters, but how it happens.

The writers of the guides show an almost studied shallowness of mind. Of one film they say: "Interesting sea story, confused by irrelevant detail and excess character development." Ah, if only these writers suffered from that same defect.

-ALBERT WILLIAM SADLER

\section{PASSION AND WORSHIP}

What is it that has made Peter Shaffer's Equus the substantive theatrical success it has been? If it achieves the distinction of becoming the play of the decade-and there seems little doubt that it will-it seems fair to say that it will have created something more than theatre history. (Sidney Lumet's realistic film adaptation will surely never have the same impact.) Equus is truly a cultural event of the richest sort. Like its decade, it is an index of quiet revolution.

The root of the play's popularity is, Ibelieve, to be found in exploring the two principal objections leveled against it. Although the critics have been fairly consistent in their praise of the play, Equus has been faulted for what is called a deliberately distorted view of psychiatry, and for concealing shallowness of thought behind the mask of brilliant theatre in its plea for passion over "The Normal."

Although theatre thrives on universal appeal, it presents individuals. The psychiatrist Martin Dysart, faced with Alan Strang's seemingly inexplicable blinding of six horses, is a particular man with his own problems. If he represents a weakness of psychiatry, he does it through the convincing revelation of his complex psyche. He stands neither for the emptiness of all healing nor for the glorification of one approach to contemporary psychiatry (R. D. Laing's equation of sanity with abnormality). Yet if the play had done nothing more than raise serious questions about the gods psychiatrists revere, about the image of wholeness that is the goal of their healing, it would have served our times well. It serves us, I propose, in a far more significant way.

The second objection is not as easy to answer; yet its resolution is linked to the first, and much more closely to the heart of the play's 